\title{
Emphysematous gastritis with hepatic portal venous gas: a shift towards conservative management
}

\author{
Fredy Nehme, Kyle Rowe, Imad Nassif
}

Department of Internal Medicine, University of Kansas School of Medicine Wichita, Wichita, Kansas, USA

\section{Correspondence to} Dr Fredy Nehme, nehme.fredy@gmail.com

Accepted 12 April 2017

\section{(1) \\ CrossMark}

To cite: Nehme F, Rowe $\mathrm{K}$, Nassif I. BMJ Case Rep Published Online First: [please include Day Month Year]. doi:10.1136/bcr-2017219651

\section{DESCRIPTION}

A female aged 94 years with a history of diabetes presented with acute onset abdominal pain, haematemesis and altered mental status. She denied alcoholism, corrosive ingestion, pancreatitis or abdominal trauma. She appeared toxic and was hypotensive. Her hemogram showed leucocytosis at $14.8 \times 10^{\wedge} 9 / \mathrm{L}$. CT scan of the abdomen showed air scattered within the liver, portal vein and gastric wall (figures 1 and 2). Also, dense calcifications of the aorta and abdominal arteries were noted (figure 3). Due to the high risk of surgery, she was managed conservatively with proton pump inhibitors, broad-spectrum antibiotics, nasogastric decompression and intravenous hydration, with progressive improvement noted.

Gastric wall gas is a rare finding secondary to two major diagnosis: gastric emphysema and emphysematous gastritis. The latter is a rare form of gastritis due to the invasion of the gastric wall by gas-forming organisms. ${ }^{1}$ Given the high mortality of emphysematous gastritis, early recognition and institution of

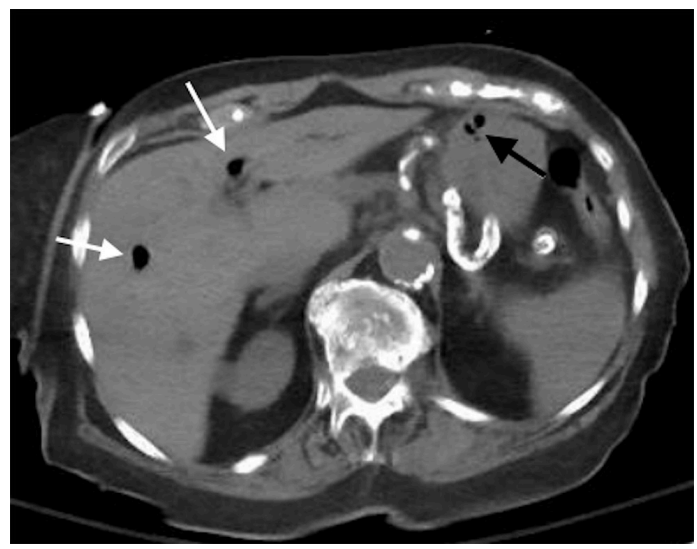

Figure 1 Axial CT scan of the abdomen and pelvis without contrast showing air within the portal vein (white arrows) and in the stomach wall (black arrow).
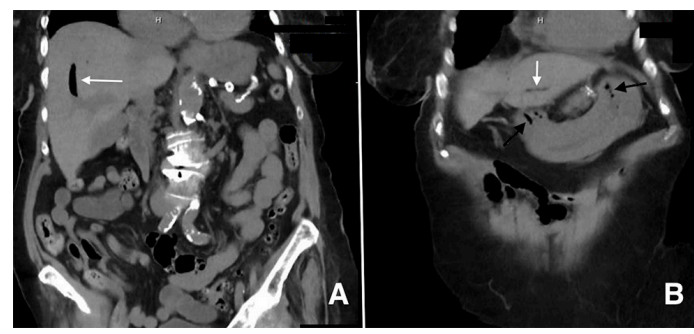

Figure 2 Coronal CT scan of the abdomen and pelvis without contrast showing air within the portal vein (white arrows) and in the stomach wall (black arrow). appropriate antibiotics, intravenous hydration and adequate nutrition are key to achieve a positive outcome.

Air within the gastric wall with concomitant portal venous system gas, hypotension, haematemesis and leucocytosis all support the diagnosis of emphysematous gastritis. The aetiology in our case is likely gastrointestinal necrosis caused by severe atherosclerosis as evidenced by her CT scan.

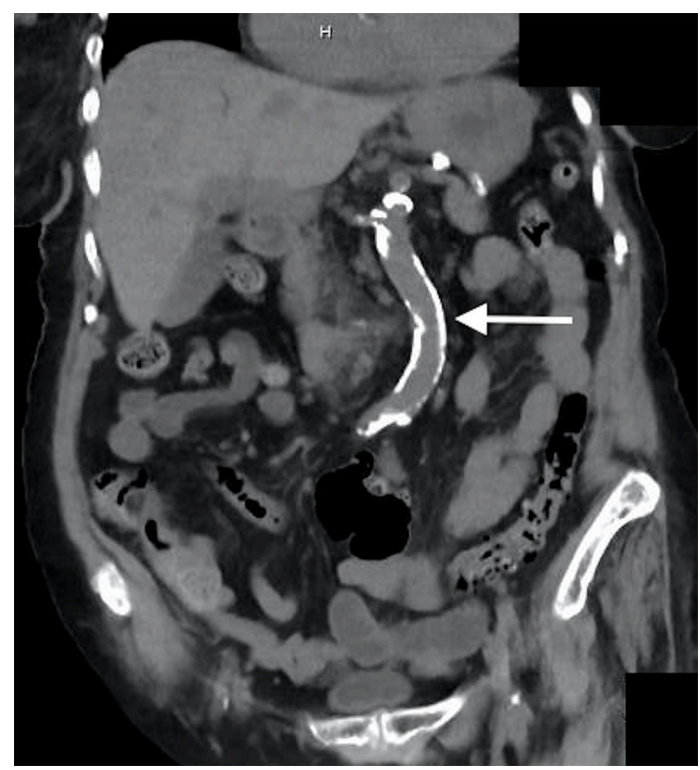

Figure 3 Coronal CT scan of the abdomen and pelvis without contrast showing dense calcifications of the aorta (white arrow).

Learning points

- When air in the stomach wall is found early differentiation between gastric emphysema (mortality rate of $60 \%-80 \%$ ) and emphysematous gastritis (excellent prognosis) is crucial to prevent further complications.

- Clinically, patients with emphysematous gastritis present with severe abdominal pain, haematemesis, fevers and leucocytosis in contrast to patients with gastric emphysema who are non-toxic appearing and usually asymptomatic.

- Radiologically, CT scan remains the best imaging modality to distinguish between both entities, as air within the stomach wall has a streaky and linear consistency in emphysematous gastritis compared with round air bubbles in gastric emphysema. 
Ischaemia increases the risk of gastric wall damage and ulcerations and subsequent invasion by gas-forming organisms.

There has been a trend towards conservative management ${ }^{2}$ with more recent reports showing improved survival. ${ }^{3}$ Surgery is only recommended in case of perforation, strictures and uncontrolled sepsis.

Contributors FN and KR drafted the manuscript and acquired the data. IN supervised and critically reviewed the manuscript.

Competing interests None declared.

Patient consent Consent obtained from next of kin.

Provenance and peer review Not commissioned; externally peer reviewed. (c) BMJ Publishing Group Ltd (unless otherwise stated in the text of the article) 2017. All rights reserved. No commercial use is permitted unless otherwise expressly granted.

\section{REFERENCES}

1 van Mook WN, van der Geest S, Goessens ML, et al. Gas within the wall of the stomach due to emphysematous gastritis: case report and review. Eur $J$ Gastroenterol Hepatol 2002:14:1155-60.

2 Szuchmacher M, Bedford T, Sukharamwala P, et al. Is surgical intervention avoidable in cases of emphysematous gastritis? A case presentation and literature review. Int Surg Case Rep 2013:4:456-9.

3 Watson A, Bul V, Staudacher J, et al. The predictors of mortality and secular changes in management strategies in emphysematous gastritis. Clin Res Hepatol Gastroenterol 2017:41:e1-e7.

Copyright 2017 BMJ Publishing Group. All rights reserved. For permission to reuse any of this content visit

http://group.bmj.com/group/rights-licensing/permissions.

BMJ Case Report Fellows may re-use this article for personal use and teaching without any further permission.

Become a Fellow of BMJ Case Reports today and you can:

- Submit as many cases as you like

- Enjoy fast sympathetic peer review and rapid publication of accepted articles

- Access all the published articles

Re-use any of the published material for personal use and teaching without further permission

For information on Institutional Fellowships contact consortiasales@bmjgroup.com

Visit casereports.bmj.com for more articles like this and to become a Fellow 